\title{
Teaching English reading skills through Oxford Reading Circle (ORC) textbook among ESL learners of grade 8
}

\author{
Tehmina Zafar ${ }^{1}$, Muhammad Arfan Lodhi ${ }^{2}$, Shamaila Iqbal ${ }^{3}$ \\ ${ }^{1}$ School Education Department district Lodhran \\ ${ }^{2}$ Higher Education Department Collegiate Wing Government of Punjab, Pakistan \\ ${ }^{3}$ School Education Department district Multan \\ 2samaritan_as@hotmail.com
}




\title{
Teaching English reading skills through Oxford Reading Circle (ORC) textbook among ESL learners of grade 8
}

\author{
Tehmina Zafar ${ }^{1}$, Muhammad Arfan Lodhi ${ }^{* 2}$, Shamaila Iqbal ${ }^{3}$ \\ ${ }^{1}$ School Education Department district Lodhran \\ ${ }^{2}$ Higher Education Department Collegiate Wing Government of Punjab, Pakistan \\ ${ }^{3}$ School Education Department district Multan \\ ²amaritan_as@hotmail.com
}

Received: $23^{\text {rd }}$ June 2021 Revised: $26^{\text {th }}$ June 2021 Accepted: $29^{\text {th }}$ June 2021 DOI: https://doi.org/10.31559/CCSE2021.2.2.2

Abstract: Reading skills though considered passive skill but play significant role in developing speaking and other skills among ESL learners. However, in the developmental process of reading skills, researchers have investigated the reading barriers that affect the learners' reading comprehension. Most specifically, the lack of using effective reading teaching strategies for the enhancement of reading skills are common in early age students. Therefore, this study validates the significance of reading skills, investigates reading hurdles, examines the reading strategies used by teachers, and manipulates the role of the Oxford Reading Circle book grade 8 in the development and enhancement of reading proficiency among ESL learners. The experimental design is applied for this research on randomly selected 50 students. Furthermore, descriptive framework was adopted to obtain teachers' perspectives about the textbook used as treatment in the experimental phase. The research tools developed for this study were questionnaires and tests. The obtained data was analyzed by using descriptive statistics technique and paired sample t-test in SPSS. The findings of current study demonstrate the importance of reading skills for ESL learners; explore the reading hurdles that learners have to face and determine the significant role of ORC book grade 8 on the enhancement of reading skills. The findings recommended that the teachers and English teaching contents both play crucial role in developing reading proficiency of ESL learners. It is also suggested that teachers should make use of effective pedagogical practices to develop reading skills habits and enhance reading proficiency among ESL learners.

Keywords: Pedagogical Reading Strategies; Reading Comprehension; Reading Barriers; Oxford Reading Circle (ORC).

${ }^{*}$ Corresponding author

Muhammad Arfan Lodhi

Higher Education Department Collegiate Wing Government of Punjab, Pakistan

E-mail: samaritan_as@hotmail.com 


\section{Introduction}

Reading skills refers to the expertise of reading of readers while reading a text. It helps the readers to read any written text that enable the readers to comprehend any written piece of work. Reading skills are very important for language proficiency. This research study is based on reading skills, reading comprehension, teaching reading, reading strategies, etc. In this study, Oxford Reading Circle is used as a tool to judge the importance of reading skills for ESL learners (Nicholas \& Claire, 2019). It also discusses the Oxford Reading Circle book's impacts on enhancing the Reading Skills of ESL learners. This research study examines the significance of ESL learners' reading skills and the effects of this book, Oxford Reading Circle grade 8, on enhancing reading skills. Oxford Reading Circle book is designed in 9 series for the students of Kindergarten to Class 8. The book Oxford Reading Circle (ORC) for Grade 8 contains literary works like the novel Great Expectations by Charles Dickens, The Purple Children by Ellis peters, etc. This book which has a masterpiece of scholarly work represents International Literature from all over the world. There is a touch of different genres of literature like prose, poetry, and novel, etc. These different genres have other themes like morality base themes, adventure, heroism, and romance, etc. These themes excited the power of imagination of children. Various drills of poetry structure and explanation are also included in this book (ibid).

\section{Background of the Study:}

There are lots of works and researches that have been conducted on reading skills. Those researches represent different strategies of reading skills and other solutions for removing the inability of reading any written text. Grover, Kullberg, and Strawser (1999) point out different reading techniques are helpful in reading comprehension. Past research discussed reading skills and different strategies and exposed the difficulties for the students that have to face while reading. Goctu (2016) addressed the solution to remove the reading barriers to read any text for students. Different writers define different definitions of reading strategies. For example, Anderson et al. (1985) discussed helpful reading strategies. They explained that we make meanings from the words which are in written form. It means that we associate the definition from our context or background knowledge. There are different strategies to enhance reading skills such as Background knowledge, asking questions, making inferences, predicting the meaning of new words, summarizing, and visualizing are the reading enhancement strategy.

In helpful strategies, background knowledge is essential to comprehend written text. Anderson \& Pearson (1984) defines background knowledge as the knowledge we got from our experiences; our previous knowledge will help connect the ideas. Besides this, Schema theory is very important in reading comprehension, which is 
discussed by Anderson \& Pearson (1984). This theory is about the formation of words and knowledge with our previous knowledge. It is based on how people form and structure words by using background knowledge and creating a series of knowledge (Goctu, 2016).

Further, Wood, Woloshyn, \& Willoughby (1995) define asking a question. Asking question is also an important factor in reading comprehension. The asking question forced the readers to think logically. This strategy helps to understand the central theme and concepts and creates focus or concentration on any written text's main topic and essential information. This strategy is related to critical thinking based on questioning, reasoning, experiments, logic, etc. It is said that the advancement of knowledge can be gained through questioning. Questioning is an essential strategy that plays a positive role in reading, as it helps to comprehend the main idea of written text. In addition, another strategy is discussed by Anderson \& Pearson (1984); Hansen \& Pearson (1983) described that making inferences is a strategy to solve the problem of students which they have to face in reading any written text. In this strategy, the reader uses background knowledge by guessing the meaning of the world and assessing the written text's conclusion. The writer doesn't give the complete form of information, and students infer by themselves. This strategy makes readers a successful reader.
Similarly, Honig, Diamond, \& Gutlohn (2000) reflected that summarizing is an essential strategy in reading comprehension. Students make précis the text in their own words that what they are reading. Students get the gist of the paragraph, which is a sign of complete understanding with the writer's written section. Readers synthesize all information and explain it all in their wordings. On the other hand, visualizing is a strategy to enhance reading capability. Readers can easily understand the written text by imagining or visualizing. Visualizing activity work only when there will be the context of the written text in readers' mind. This strategy is beneficial in memorization when learners visualize and read the text, and then the images are automatically built up and saved in their mind. So, there are lot of effective strategies that a teacher and learner can use for effective and developmental results of reading skills of ESL learners.

The grammar of a language is an essential aspect of learning the language. Without grammar, the purpose of language's origination will be unsuccessful. Removing the weaknesses of grammar is also a great solution to improve reading skills by using different effective reading strategies. Grammar is an essential feature of the language, and it can be said that "Grammar is a track on which language run." The difference of this research study is that it will explore difficulties of reading and define the role of ORC in grade 8 (Nicholas \& Claire, 2019). Reading 
skills are the most and foremost skills which become the fundamental need of learners to learn the language. But there are hurdles to develop the reading expertise of learners. Reading barriers are hindrances to learn any language. Learners, especially in Pakistan, have to face many difficulties because they are not facilitated with native accent teachers; their medium is Urdu which is their mother tongue. Lack of reading skills is a severe issue for $2^{\text {nd }}$ language learners.

Reading issue has more significant impacts on readers' reading skills. Most important, reading is the primary tool that permits the students to analyze, synthesize, and assess the written materials and exercise it at a higher level of thinking skills. Reading is an essential source of autonomous learning, whether reading is to improve language proficiency or learn related about the subject. Reading is a significant and dire need of our society. Writing is also the main tool and secondary need, which is used to express ideas or concepts (Syahfutra, 2017. Writings also share feelings. In the modern era, learners are habitual to use technical accessories like cell phones, tabs, computers, etc. So, these new specialized instruments run in the English language. Present-day is attached with modern technology, and most students spend their more precious time on Facebook, WhatsApp, Instagram, and online games rather than on reading their textbooks.

Moreover, the significance of information technology cannot be denied, but these modern technologies represent the importance of reading. If writing is there, then reading will also be there. Reading is a primary need, and writing is a secondary need of learners. In this situation, readers and learners cannot ignore the importance of reading. Reading is one of the most effective complex mental processes that involve the uniqueness of the human mind. Reading skills' issue demands a solution. So, this research study will also focus on reading difficulties, comprehension problems of learners. The researchers (Guo, 2011; Syahfutra,2017; Goctu, 2016) have mentioned how to develop reading skills and how to tackle reading problems in the present day. These researches discuss the reading skills, different strategies and expose the difficulties for the students who must face while reading. They also give solutions to remove barriers of reading any text for students.

\section{Statement of the Problem:}

Reading skills play an essential role for learners. Avoiding reading proficiency is an alarming situation for learners in the way to acquire English language proficiency and communication skills. This research study is an attempt to examine deficiency and hurdles regarding developing reading skills, comprehension issues, lacking different helpful strategies in improving reading skills, and its aftermaths if readers ignore these skills. The study discusses the role of Oxford Reading Circle grade 8 in developing reading proficiency. It further highlighted the importance of Reading skills and the reading barriers 
International Journal of Childhood, Counselling, \& Special Education (CCSE), Volume2, Issue2, June: 2021, pp.85-102

confronted by learners during developing their English reading proficiency.

\section{Research Questions:}

1. What is the importance of reading skills for ESL learners?

2. What are the hurdles that students have to face while reading text?

3. How do students enhance the reading skills by using the Oxford Reading Circle book?

4. How does Oxford Reading Skills (ORC) Grade 8 meet the desired needs of ESL learners?

\section{Review of the related Literature}

\section{English Reading Skills:}

Reading is an essential skill to comprehend the written text. Reading without comprehension is just wasting time. Comprehension and understanding are a complex phenomenon that requires perception and thought. Reading is the way of enhancing reading skills, which means reading any written text, novel, journal, etc. It is not an easy task. Development of understanding through the text is, to some extent, a challenging task for the mind. Reading is a language process in which learners are ready to receive new ideas and new concepts regarding the written text. Reading is the process of identifying, interpreting, and percept the written text. Reading has a great significance in understanding a written piece of text correctly and proficiently. Reading is an essential tool in all fields of learners' life. According to Abdul (2006), reading can be the source to advance the English contextual knowledge and widen their ideas, motivate their thoughts, build their morals, artistic performance, and increase their intellect.

Hayati, Ahmet, Hayriye (2014) stated that reading is the method that includes the following definition: reading means inferring, knowing correct sounds, and comprehension. Students can comprehend the written text by applying helpful strategies. They stated about the identification of barriers that readers must face a lot of problems while reading because they are unable to comprehend the text that is the biggest issue in reading obstacles. Comprehension problems begin when students cannot apply his/ her prior knowledge, unable to connect previous knowledge to the next new one. Readers have lacked functional skills in perceiving/ getting the unity of meaning. An enrichment reading program is beneficial for the students. They stated that correct words, correct pronunciation and perception, proper sentence structure, linguistics process, and comprehension are part and parcel. These are the base of healthy reading. Pilten (2009) stated that good readers could recognize words automatically, and he/she can easily differentiate.

Grellet (2001) stated that reading is a mental development that activates the eyes' muscles. Reading is a thoughtful activity that includes a lot of attention, consideration, cognition that helps to enhance the reader's everyday communicational skills. Reading enhances knowledge, which is helpful for readers. Reading skills helps the readers to understand new words 
and idioms that they must confront in their daily everyday life.

\section{Types of English Reading:}

Patel and Praveen (2008) described some reading types, such as Intensive reading, Extensive Reading, Aloud Reading, and Silent Reading.

Intensive reading involves the intensity to read any text. It focuses on idiom and vocabulary that the teacher teaches in the classroom and phrase and vocabulary, including different genres, i.e., poems, poetry, novel, or any other source. Other type of reading is extensive reading in which learners read any text for his/her enjoyment and pleasure. There are various theories of the ER. Krashen had done a lot of works in this regard. Aloud reading refers to the reading with voice. It uses loudness and clarity, for example, reading dialogue, poetry, and other types of text. Furthermore, Silent reading is an activity in which learners read the without their voices. It is opposite to the aloud reading. It can be said that it is voiceless activity that the students use to get attention and get the concept of written text. In this activity students read a text by their heart and concentrate on text by their eyes.

\section{English Reading Comprehension:}

Comprehension

means understanding, getting the central theme, and being familiar with situations, facts, etc. Reading comprehension is a process that involves both, the mental and cognitive ability of learners to understand the written text. English Reading Comprehension is an essential tool for ESL learners. This comprehension skill must be developed by parents at home and by teachers in classrooms because it is very important for the academic and professional success of learners. According to Al Noursi (2014), learning ability is a precursor to successful learning in schools, colleges and universities. He further added that reading ability is a vital skill that exists all over the world because of its demand, not only for the learners but also for the professionals in the 21st century. On the other hand, Dagget and Hasselbring (2007, p. 1) considered reading skills is an important factor of learning that leads towards the academic proficiency.

\section{Reading Barriers:}

Barriers refer to the hurdles and difficulties which are faced by someone in any task or activity. Barriers play a negative role in adopting something positive and reading barriers about the problems of the reader, especially for ESL learners. These hurdles make a stone wall for learners to embrace any positivity (Nakanishi \& Ueda, 2011). As this study mentioned, the significance of reading habits, which are a positive factor in the personality of learners. But behind this significance, learners have to face a lot of difficulties in reading. Reading is not an easy or straightforward task; it is a strenuous activity because learners have to not only read word by word but also read the text according to the context. There are lot of difficulties and hurdles are faced by the learners that are mentioned below.

\section{Lack of vocabulary}


Vocabulary refers to the collection of words regarding the language. ESL learners have to face the difficulty of lacking vocabulary. Vocabulary is an essential part of reading. When learners and readers have a vocabulary, then he/she can easily understand the text. But unfortunately, learners have a little bit of store of vocabulary, and they don't enhance vocabulary. According to Guo (2012), vocabulary can be improved by memorizing the words, and memorization is not enough for vocabulary, but students' interest plays a vital role in this process. Learners must adopt useful activities for enhancing the vocabulary because it paves the path of learners for reading. Lack of vocabulary demotivates the students for reading. This is the biggest hindrance in developing reading habits.

\section{Lack of Pronunciation Skills}

Pronunciation refers to the sound of a word, the sound which is comprised of consonants and vowels. Learners are unable to recognize the word according to its pronunciation. Many students are unable to identify the silent sounds, i.e., the spelling of psychology creates confusion for the learners in pronouncing the letter P. In this dilemma, learners feel confusion to produce the words, especially to read words in a loud voice. In this way, they skip readings that affect or create poor reading habits.

\section{Anxiety}

Anxiety about the uneasy situation creates a hindrance in doing any user activity. Fear in reading is the primary cause of poor reading habits. Learners feel the stress to pronounce a new word, and learners even don't consult with teachers because of the wrong pronunciation. This is due to the lack of confidence, which creates a perplexing situation for learners. Hayati, Ahmet, Hayriye (2014) stated that anxiety is the biggest hindrance in reading skills. Stress is different steps of reading like pronouncing a correct word, fear in confronting new words, etc., are the hurdles to discourage the students from developing reading habits (Guo, 2012). This depressed and stressed environment creates unsuccessful learners.

\section{Lack of Background Knowledge}

Another factor of poor reading habit is the lack of previous knowledge. When learners read any written text, they are unable to understand the passage according to the point of the writer. Without background knowledge, students feel difficulty to understand according to its context. Learners don't know the explicit and implicit meanings of the words. This ignorance regarding knowledge leads to poor reading habits (Al Noursi, 2014).

\section{The poverty of useful Strategies}

Many students are not conscious about the useful strategies regarding the reading. Reading is a complex task, but it can be made an easy task by using different tactics. Learners are unable to use these tactics even they don't know the reading strategies, which are helpful to increase the reading skills of ESL learners. Skimming, scanning, reading in chunks and the SQ3R formula is proved beneficial for ESL learners to enhance their skills (Nakanishi \& 
Ueda, 2011). Not only strengthen their reading skills but also develop an interest in the student and forced them to think analytically regarding the written text. Learners easily interpret the text and analyze the whole passage according to the desire of the writer. But these skills are not available to the students and learners; that is why they have to face hurdles while reading the complicated text.

\section{Lack of willingness}

Willingness is an important factor to enhance or develop the habits of reading. Interest and curiosity forced the learner to be willing to do anything. ESL learners are not ready to learn the language, and they don't feel any need for reading. Learners' interest plays a vital role in reading. Learners, especially at the Elementary level, don't show interest, and even they don't like the English language because of its complication. They don't develop an interest in reading. Interest and willingness forced the learners to read and the Elementary level; this factor is ignored.

\section{Teaching Reading Skills:}

Nakanishi \& Ueda, (2011) conducted study upon effect of extensive reading and shadowing on learners' proficiencies. According to them, learning and teaching reading skills are active, innovative and though instigating set of processes and procedures. Teaching reading is a complex process in which teachers' role cannot be denied. The best teachers create a comprehensive knowledge base and develop a set of strategies for working with struggling students. Reading is a skill of language that plays an important role for ESL learners. For example, there are a lot of magazines, articles on the Internet, some articles can be found in English that are used to touch with current affairs and knowledge (ibid). There are different stages of teaching reading as; pre reading, post-reading, and whilst reading

\section{Skimming}

This is reading strategy that is used by readers when they want to skim the passages. Learners have to pay attention to its surface, to get a general idea of what a text represent. For example, readers read an article, there they don't want to read each and every word like in bottom-up technique, they just focus on main points i.e., abstract, first and last lines of introduction, read the bold headings and lastly read the conclusion of article. After these steps, readers become able to understand the writers' concept. Maxwell (1969) quoted in Dias, S \& Lagoado, J (2013, pp 138) stated that skimming is a strategy of quick understanding of written text, students get the gist of passage by skimming and they use inference skills to know the summary of text. So, it can be said that skimming is the way to find the keywords that helps the students to interpret the passage quickly and this process increase their reading skills. Winardy (2010: 15) and Grelet (1981: 19) stated about the advantages of skimming that is as follows:

- This strategy helps the readers to get the main concepts quickly.

- Students obtain knowledge about the text structure.

- Readers are able to perceive the writers' concept and this strategy is 
source of joy because it avoids boredom of long time reading.

\section{Scanning}

Scanning is another strategy that is very interesting because it focuses on the specific, required information. Readers use this strategy when they want to locate specific information from written text. For example, they find out the specific word from dictionary, search phone number from directory and google any particular article. So, in this strategy, there is no need to read every word but focus on particular word that the readers want to know and find out. According to Maxwell (1970) in Dias, S \& Lagoado, J (2013, pp 138), definition of scanning is to find out specific information, search particular required word and it can be any number, names, words, address etc. There are some advantages to scanning. There are as follow:

- This strategy emphasizes to find out the specific information that required students' active participation and active visual process.

- Students are straightforward to specific required information in written passages.

- Readers save their time by using this strategy.

\section{SQ3R}

SQ3R is a reading strategy that a reader uses to read actively. Syahfutra (2017) indicated the SQ3R strategy as most effective reading system for knowledge acquisition and learners' retention. By this strategy, readers save their time.
- "S" refers to the survey that means collect the information from written text, read the summary, title, introduction paragraph to get the main concept of text and the writers' intentions. Through the survey, readers gather information from highlighted words, headings that help them to make a framework, and proper structure of text before the start of reading. Readers also focused on pictorial representation of text i.e., images, graphs, charts, diagrams to understand the point of written text.

- “Q” means questions, readers think logically, focus on the text, engage their mind by focusing on the boldface words. When readers make question, then they develop their understanding, and in this way, they can add more question for further understanding of text. This process develops their learning, and they learn from raising questions Ness, 2011).

- "R" refers to read, readers read each section of text with the questions that they already raise from the highlighted words. They highlight the answer of question that are created in their mind, and summarize the important information of text (Syahfutra, 2017).

- "R" means for recitation, readers absorb all the information through reading. After the reading of section, they memorize the question that they raise before reading the whole section and try to give answer after reading the 
section without seeing the text, using memory. In this process, readers are not allowed to read further until they completely understand the text. So, memory in very important in this stage (Guo, 2012).

- "R" refers to the review of text after reading. Readers review the whole text after completing the reading, this helps them to memorize the important information and give better understanding of text.

Textbooks to teach English Reading Skills

A textbook is commonly used to teach any subject by a teacher. Textbooks are not used only for student but also for the common people who read just for information. People use a textbook to learn the facts and methods of a topic. There are different types of textbooks i.e., testing books, knowledge and facts-based textbooks, teaching textbooks etc. Different textbooks are used for different purposes. Purpose can be only to get information, to teach student, different workbooks to practice and to enhance their skills. There are some books that are used to teach reading comprehension. It is an important for readers to develop their reading skills and reading interest. Therefore, teachers use different effective textbook, from where they get better understanding that what they are reading and comprehension of written text (Ness, 2011). Understanding of text is very important in the reading process because without understanding, the process of reading is just wastage of time. For the purpose of comprehension skills, there are a lot of textbooks in the market to enhance the learners' reading skills.

\section{Research Methodology}

\section{Research Design:}

The design of this research study is descriptive and experimental. in this study, the researcher handles one independent variable and another dependent variable.

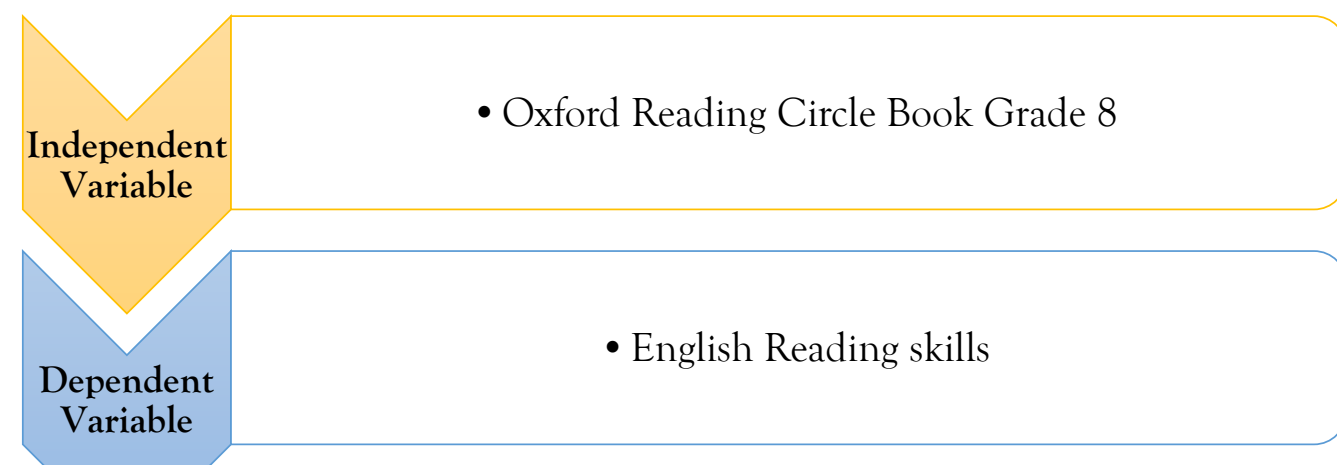

A population is a whole set of persons, objects, etc. that is used to conclude, and the sample is a subset of the population that is used to collect data. The population of this 
International Journal of Childhood, Counselling, \& Special Education (CCSE), Volume2, Issue2, June: 2021, pp.85-102

research study was the public schools of District Lodhran. Sample refers to the selected person, objects, etc. for participation in the study. It can be defined as the small portion of the population for the research study. The sample of this research study has consisted of 50 students of grade 8 and 40 teachers. The data was collected by developing questionnaires and Reading proficiency tests. The tools were piloted before administration to ensure validity and reliability.

Table (1): Distribution of the sample

\begin{tabular}{lcc}
\hline Sr\# & Total Students Sample & Total Teachers Sample \\
\hline 1 & 50 & 40 \\
\hline
\end{tabular}

study. Students are divided according to

The researchers used random sampling technique for this research the following groups:

Table (2): Distribution of Students' group

\begin{tabular}{lllll}
\hline Sr\# & \multicolumn{2}{c}{ Control Group } & Experimental Group \\
\hline $1 .>$ & $\begin{array}{l}\text { Comprised of 25 students, } \\
\text { taught through } \\
\text { Textbooks. }\end{array}$ & $>$ & $\begin{array}{l}\text { Consisted of 25 students and } \\
\text { taught through ORC book } 8 .\end{array}$ \\
\hline
\end{tabular}

\section{Analysis and Discussions}

\section{Data obtained from Teacher's Questionnaire:}

A questionnaire tool was used for 50 teachers to know their views about reading skills. Findings of the data obtained from the questionnaire are discussed below:

Different reading related questions were asked from the teachers to know the significance of reading skills for ESL learners. It was asked that reading English is important for ESL learners and around $92 \%$ of teachers were agreed. Reading builds language competency, supported by $87 \%$ respondents. The majority of the $89 \%$ of respondents showed their positive responses regarding the advancement of knowledge through reading skills. Reading skills helps the learners to write and critique the written text, this statement was supported by $70 \%$ of respondents. Further, the majority $75 \%$ of respondents showed their will about the role of English reading skills in academic and professional life. Around $70 \%$ of respondents were agreed that reading is the source to collect information. $97 \%$ positive responses rectified that reading strategies are important for learners to enhance their reading skills. Around $87 \%$ of respondents gave positive feedback about the different reading tactics that skimming, scanning, SQ3R are very important to enhance the reading skills of learners. These strategies play a pivotal role to increase the reading proficiency of learners that is preferred by many other researchers. Further, $97 \%$ of the respondents were agreed that the reading barrier affects reading skills. 95\% respondents were agreed that tough vocabulary, fear, anxiety for 
International Journal of Childhood, Counselling, \& Special Education (CCSE), Volume2, Issue2, June: 2021, pp.85-102

reading and lack of motivation discourage the ESL learners to develop their reading skills.

\section{Data obtained from Proficiency Test:}

The test was developed to highlight the gap between existing reading performance through Govt.

Table (3): Analysis of Total Pre-Test and Post-Test between Control and Experimental Group

\begin{tabular}{cccccc}
\hline \multicolumn{5}{c}{ Paired Samples Statistics } \\
\hline Pair & Mean & N & $\begin{array}{c}\text { Std. } \\
\text { Deviation }\end{array}$ & $\begin{array}{c}\text { Std. Error } \\
\text { Mean }\end{array}$ \\
\hline $\begin{array}{c}\text { Pair } \\
2\end{array}$ & $\begin{array}{c}\text { Total Pre-Test of Control } \\
\text { Group } \\
\text { Total Pre-Test of } \\
\text { Experimental Group } \\
\text { Total Post-Test of Control } \\
\text { Group }\end{array}$ & 24.3600 & 25 & 4.37683 & .87537 \\
& $\begin{array}{c}\text { Total Post-Test of } \\
\text { Experimental Group }\end{array}$ & 27.0000 & 25 & 2.97209 & .59442 \\
\hline
\end{tabular}

The findings show that there is a hugely significant difference between the pre-test and post-test of the students. Table 3 indicates the comparison of total pre-tests between the control and the experimental group and total post-test between control and experimental group. As the findings indicate that there is no significant difference in the pre-test between the control group and the experimental group. The mean in the control group of pre-tests is 24.3600 and mean in experimental group of pre-tests is 27.0000. Standard deviation of control group is 4.37683 and in experimental group, standard deviation is 2.97209. On the other side, there is huge difference in posttest between control group and experimental group. The mean in the post-test of the control group is 26.1200 and in the experimental group, the mean is 37.4800 . It shows textbooks and the performance after teaching the ORC book Grade 8. Test was analyzed through the paired sampling technique in SPSS.

1. Analysis of Total Pre-Test and PostTest between Control and Experimental Group the significant difference between the control and experimental group. It can be concluded that the ORC book Grade 8 can play its important role in the enhancement of the reading skills of ESL learners.

\section{Analysis of Skills in Pre-Test and}

\section{Post-Test}

Tests were designed to know the students' ability to read the text before and after teaching them the ORC book grade 8 . Tests consisted of 40 marks. Different skills were examined through tests.

\section{Description of Skills:}

- S1 was based on grammar skills that were tested through tenses and verbs' activities.

- S2 was based on vocabulary skills that were checked through synonyms, antonyms, words, sentence activities. 
International Journal of Childhood, Counselling, \& Special Education (CCSE), Volume2, Issue2, June: 2021, pp.85-102

- S3 was based on referential skills. Different activities are asked to know their ability of inference.

- S4 was based on comprehension skills that were tested through written passages' activities. In this activity, the skimming, scanning, and inference ability of students were analyzed.

Here is the detailed skill-wise analysis of pre-test and post-test of control and experimental group.

Table (4): Analysis of Skills in Control Group

\begin{tabular}{|c|c|c|c|c|c|}
\hline \multicolumn{6}{|c|}{ Paired Samples Statistics } \\
\hline & & Mean & $\mathrm{N}$ & $\begin{array}{c}\text { Std. } \\
\text { Deviation }\end{array}$ & $\begin{array}{l}\text { Std. Error } \\
\text { Mean }\end{array}$ \\
\hline Pair & $\begin{array}{c}\text { S1 of Control Group in } \\
\text { Pre-Test }\end{array}$ & 4.8000 & 25 & 1.35401 & .27080 \\
\hline 1 & $\begin{array}{c}\text { S1 of Control Group in } \\
\text { Post Test }\end{array}$ & 5.1200 & 25 & .78102 & .15620 \\
\hline Pair & $\begin{array}{c}\text { S2 of Control Group in } \\
\text { Pre-Test }\end{array}$ & 3.8800 & 25 & .97125 & .19425 \\
\hline 2 & $\begin{array}{c}\text { S2 of Control Group in } \\
\text { Post Test }\end{array}$ & 4.5200 & 25 & .82260 & .16452 \\
\hline Pair & $\begin{array}{c}\text { S3 of Control Group in } \\
\text { Pre-Test }\end{array}$ & 3.4400 & 25 & 1.00333 & .20067 \\
\hline 3 & $\begin{array}{c}\text { S3 of Control Group in } \\
\text { Post Test }\end{array}$ & 4.3200 & 25 & .98826 & .19765 \\
\hline Pair & $\begin{array}{c}\text { S4 of Control Group in } \\
\text { Pre-Test }\end{array}$ & 2.4800 & 25 & 1.38804 & .27761 \\
\hline 4 & $\begin{array}{c}\text { S4 of Control Group in } \\
\text { Post Test }\end{array}$ & 4.1200 & 25 & 1.12990 & .22598 \\
\hline \multirow{2}{*}{ Pair 5} & $\begin{array}{l}\text { Total Pre-Test of } \\
\text { Control Group }\end{array}$ & 24.3600 & 25 & 4.37683 & .87537 \\
\hline & $\begin{array}{l}\text { Total Post Test of } \\
\text { Control Group }\end{array}$ & 26.1200 & 25 & 3.29545 & .65909 \\
\hline
\end{tabular}

Table 4 indicates the skills differences in pre-test and post-test among the students of control group. Both pre-test and post-test was conducted from students and their result didn't indicate significant differences in their performance. Table indicates the no differences of mean in the above mentioned 4 skills of test. The mean in total pre-test of control group is 24.3600 and in posttest is 26.1200 . The mean differences between pre-test and post-test show that there is a little bit differences in tests.

Table (5): Analysis of Skills in Experimental Group

\begin{tabular}{|c|c|c|c|c|c|}
\hline \multicolumn{6}{|c|}{ Paired Samples Statistics } \\
\hline & & Mean & $\mathrm{N}$ & $\begin{array}{c}\text { Std. } \\
\text { Deviation }\end{array}$ & $\begin{array}{c}\text { Std. Error } \\
\text { Mean }\end{array}$ \\
\hline Pair & $\begin{array}{l}\text { S1 of Experimental Group } \\
\text { in Pre-Test }\end{array}$ & 9.5200 & 25 & .71414 & .14283 \\
\hline 1 & $\begin{array}{l}\text { S1 of Experimental Group } \\
\text { in Post-Test }\end{array}$ & 9.7600 & 25 & .54237 & .10847 \\
\hline Pair & $\begin{array}{c}\text { S2 of Experimental Group } \\
\text { in Pre-Test }\end{array}$ & 7.1400 & 25 & 1.05594 & .21119 \\
\hline 2 & $\begin{array}{l}\text { S2 of Experimental Group } \\
\text { in Post-Test }\end{array}$ & 8.7800 & 25 & .45826 & .09165 \\
\hline
\end{tabular}


International Journal of Childhood, Counselling, \& Special Education (CCSE), Volume2, Issue2, June: 2021, pp.85-102

\begin{tabular}{cccccc} 
Pair & $\begin{array}{c}\text { S3 of Experimental Group } \\
\text { in Pre-Test }\end{array}$ & 6.0200 & 25 & 1.41774 & .28355 \\
3 & $\begin{array}{c}\text { S3 of Experimental Group } \\
\text { in Post-Test }\end{array}$ & 9.4200 & 25 & .55302 & .11060 \\
$\begin{array}{c}\text { Pair } \\
4\end{array}$ & $\begin{array}{c}\text { S4 Experimental Group } \\
\text { in Pre-Test }\end{array}$ & 4.3200 & 25 & 1.54704 & .30941 \\
$\quad \begin{array}{c}\text { S4 of Experimental Group } \\
\text { in Post-Test } \\
\quad \text { Total Pre-Test of } \\
\text { Pair }\end{array}$ & 9.5600 & 25 & .74050 & .14810 \\
$5 \quad \begin{array}{c}\text { Experimental Group } \\
\text { Total Post-Test of } \\
\text { Experimental Group }\end{array}$ & 27.0000 & 25 & 2.88675 & .57735 \\
\hline
\end{tabular}

Table 5 indicates the skills analysis in pre-test and post-test of experimental group. Both pre-test and post-test were conducted from the experimental group and differences between them are indicated through the paired sampling technique. The mean in the total pre-test of experimental group is 27.0000 and the mean in the total post-test of experimental group is 37.4800. This difference shows huge significant differences in the performances of students before and after the test. It can be concluded that reading specified books such as ORC book grade 8 are very helpful to get proficiency in reading and these are the best source of development of reading skills of ESL learners.

3. Data obtained from the Post treatment Questionnaire

A post treatment questionnaire tool was developed for 25 students to get the reviews about treatment as manipulation check of independent variable (i.e. ORC pedagogy). Students gave confident responses about the role of ORC book grade on the enhancement of reading skills. 100\% of the respondents were agreed about the improvement of reading skills through the ORC book. Then students were asked about the role of ORC in the improvement of grammar skills of learners and $100 \%$ of respondents were agreed to its' positive role. Then, $100 \%$ positive responses were received about the role of the ORC book in stimulating the power of imagination of learners. Many students were agreed that it enhanced their imaginational power by reading of its story content. The findings represent the role of ORC in the enhancement of vocabulary and $100 \%$ of respondents showed their favor for its role. Many students increased their level of vocabulary after reading the ORC book.

The findings indicate that $68 \%$ were agreed with its' role in the improvement of language competence. 96\% of respondents improved their comprehension skills through the ORC book. Many students developed their concepts and understanding by reading it. The findings represent that $100 \%$ of students were motivated by the interesting contents of ORC. It helped them to read more and developed reading habits. Results indicate that $96 \%$ of students were agreed that it develops the curiosity to read more. Results show the response about its' attraction through pictorial representation. $100 \%$ of respondents gave the confident response that colorful pictures attracted them to read more. 
Justification of the Research Questions

1. What is the importance of reading skills for ESL learners?

Reading skills are very important that are indicated through the responses of teachers in this study. The majority of teachers are favored with the significant role of reading skills for ESL learners. Reading skills are important that is emphasized by many other studies. Sloat, Beswick, \& Williams (2007) reflected that it is very important for students to get proficiency in reading before reaching the third grade because, after the third grade, students begin to acquire knowledge and learn from academic content. In addition, students who fail to master the reading skills at the end of 3rd grade are less motivated for learning, behavioral challenges, and lower academic achievement. Findings obtained in this study affirm that reading skills hold crucial importance to acquire language proficiency in students' and teachers' perspectives. However, the importance factor is not justified well in theory and practice on the part of learners and students. The reading skills though falsely considered as passive skill, actually play active role in acquiring reading and writing competencies among ESL learners.

2. What are the hurdles that students must face while reading English texts?

The second research question is aimed to investigate the role of reading hurdles. Reading barriers affected the reading skills of ESL learners. The findings indicate that reading barriers affect the performance of ESL learners.
Many research studies highlighted this issue. Difficulty in reading leads the learners to the failure of academic success. These difficulties create disliking, disinterest, demotivation for learners in reading; consequently they fail to develop their reading skills. Seeds (2010) stated that those students who face difficulty in reading may experience a lifetime dislike for reading. Reading hurdles can affect the reading attitudes of readers (Luke 2013). Reading barriers create poor reading skills. Students with poor reading skills are at serious risk of academic failure (Obadia \& Thériault, 1997; Snowling, 2000; Savage, Carless, \& Ferrero, 2007). The results highlight multidimensional impediments including attitudinal, psychological, motivational, pedagogical and emotional issues which learners come across during reading academic or nonacademic English texts.

3. How do students enhance the reading skills by using the Oxford Reading Circle book?

The third research question of this study is to know the significant role of the ORC book Grade 8. To meet the answer of this question, the test was developed for the students of grade 8 . The test was comprised of four basic skills i.e., vocabulary skills, grammar skills, inferential skills, and comprehension skills, consist of different effective reading strategies. Students were asked to attempt all questions voluntarily. Their performance in tests, pre, and post, is indicated in the research findings. The findings indicate the huge difference between the pre-test and post-test of 
the students in grade 8 . ORC book grade 8 plays an important role to enhance the reading skills that are highlighted through the pre-test and post-test of students. The mean difference of control and experimental group in pre-test and post-test, shows a great significant difference before and after the reading of the ORC book. The results also indicate the skill-wise performance of students and the mean differences represent the significant role of ORC book grade 8. After reading the book, students were motivated to read more and it developed their interest in reading. Its excellent pictorial representation helped them to carry on the reading. The excellent performance in tests shows that students get motivation, interest, and curiosity to read the book and these are the important factors in the development of reading skills of ESL learners.The findings help to conclude that teachers must use the reading specified books. They must facilitate the students with such effective reading textbooks that help the learners to be a good reader. So, teaching English reading is very important for the development of reading skills for ESL learners.

- How does Oxford Reading Skills (ORC) Grade 8 meet the desired needs of ESL learners?

The fourth research question is to find out the positive impact of the ORC book on the needs of ESL learners. The answer to this research question was gained by developing the post-questionnaire. No doubt; ORC helps to meet the desired need of ESL learners by giving excellent content.
Students' excellent performance indicates the importance of the ORC book and students were motivated to read its story contents. Its pictorial representation developed the interest which helped them to enhance their reading skills. Accordingly, second language teachers need to be aware of these preferences to help language learners to find the best way to develop their language skills. The findings of the current study reveal that most of the participants had positive perceptions toward using the ORC book to develop their reading competency. The use of these types of reading specified books depends on the purpose of the reading. Teachers must aware about to use of reading textbooks for the enhancement of the reading proficiency of ESL learners. To explain, there are some reading methods and styles that can be espoused by teachers and learners to boost up their reading skills such as; skimming, scanning, silent, and aloud reading can be used to increase the reading speed and to enhance the understanding of the written text.

\section{Conclusion}

This study is an attempt to highlight the importance of reading skills for ESL learners and expose the different barriers that students or learners have to face while reading. This study also investigates the role of ORC book grade 8 on the enhancement of the reading skills of ESL learners. The finding helps to conclude this study by highlighting the significant role of reading skills and the importance of English reading 
textbooks for learners. The development of reading skills, especially at an early age and at the level of the school, is very important in the life of ESL learners. ESL learners need proper guidance at school-going age which is provided by teachers and parents. It is very important to enhance or laid down the foundation of the development of reading skills at the initial level. Teachers and parents must motivate the learners to read English textbooks and they must make this process easy for them by promoting useful reading strategies. This study highlights the importance of English reading textbooks for ESL learners through the experiment. With the help of a test and questionnaire, the researcher is able to conclude this study. Reading contents and textbooks are very important to enhance the reading skills such as the ORC book Grade 8 . The study further advocates the awareness and inclusion of multifaceted reading strategies by English teachers in their classes. Most commonly used reading techniques are skimming, scanning, intensive reading strategies, extensive reading strategies, SQ3R method, ERRQ method, and $\mathrm{KWL}$ reading methods.

\section{Recommendations}

1. Reading skills are the basic need of ESL learners, so it must be developed by the learners' own will. Their positive attitude makes the process of reading easy for them and helps them to enhance their reading skills. As reading is the key to success in academic and professional life. For academic and professional success, learners must develop their reading skills.

2. As reading is the source of information, learners must have the command of reading to get the information around the world. It can be developed by the interest in reading for learners. Interest and motivation, both are important aspects for the enhancement of reading skills. Motivation may be extrinsic or intrinsic, must be used for learners, so that they can compete with the world. Teachers use motivational techniques for learners, which lead to the development of reading habits.

3. Teachers and parents play a great role in developing the reading skills of ESL learners. Teachers must emphasize the reading activities and parents must also motivate the students for reading. Teachers must use reading specified material they must use effective reading strategies to develop their reading skills.

4. Curriculum designers must design an interesting curriculum. Content must be interesting, and it must develop the curiosity to read more. It must stimulate the power of imagination of learners. It must have interesting colorful pictorial representations of story contents.

\section{References}

Abdul Halim Ibrahim, (2006). The Process and Problems of Reading. Masalah Pendidikan.

Anderson, R. C., \& Pearson, P. D. (1984). A schema-theoretic view of basic processes in reading. In P. D. Pearson, R. Barr, M. L. Kamil, \& P. Mosenthal (Eds.), Handbook of reading research (pp. 255-292). New York: Longman. 
International Journal of Childhood, Counselling, \& Special Education (CCSE), Volume2, Issue2, June: 2021, pp.85-102

Retrieved

from http://hdl.handle.net/2142/31284

Anderson, R. C., Hiebert, E. H., Scott, J. A., \& Wilkinson, I. A. G. (1985). Becoming a Nation of Readers. Washington, D. C.: National Institute of Education.

Dagget, W., \& Hasselbring, T. (2007). What we know about adolescent reading. International Center for Leadership in Education. Retrieved from

http://www.leadered.com/pdf/what we know ab out adolesent reading 2014. Pdf

Goctu, R. (2016). The Impact of Reading for Pleasure on Georgian University EFL Students' Reading Comprehension (IBSU Case). Journal of Education in Black Sea Region. $1(2)$ :

73-81,

https://doi.org/10.31578/jebs.v1i2.20.

Grellet, F. (2001). Developing reading skills. Beijing: Foreign Language Teaching and Research Press.

Guo, S.c. (2012). Using Authentic Materials for Extensive Reading to Promote English Proficiency. English Language Teaching, 5(8): 196-206, https://doi.org/10.5539/elt.v5n8p196.

Grover, S., Kullberg, K., \&Strawser, C. (1999). Improving Student Achievement through Organization of Student Learning. International Education Journal, 5 (4).

Hansen, J., \& Pearson, P. D. (1983). An instructional study: Improving the inferential comprehension of fourth grade good and poor readers. Journal of Educational Psychology,75(6), 821-829. http://dx.doi.org/10.1037/0022-0663.75.6.821.

Honig, W., Diamond, L., \& Gutlohn, L. (Eds.). (2000). Teaching reading sourcebook for kindergarten through eighth grade. Novato, CA: Arena Press; National Reading Panel.
Lukhele, B.B.S., (2013). Exploring relationships between reading attitudes, reading ability and academic performance amongst primary teacher trainees in Swaziland. Reading $\mathcal{E}$ Writing, 4(1), 1-8, https://doi.org/10.4102/rw.v4i1.28.

Nakanishi, T. \& Ueda, A. (2011). Extensive reading and the effect of shadowing. Reading in a Foreign Language, 23(1): 1-16.

Ness, M. (2011). Explicit Reading Comprehension instruction in Elementary Classroom: Teacher Use of Reading Comprehension Strategies. http://lchc.ucsd.edu/MCA/Mail/ xmcamail.2013 09.dir/pdfXrptHTp61Y.pdf.

Nicholas, H. \& Clare, H. (2019). Oxford Reading Circle 8. Oxford University Press.

Noursi, O. A. (2014). Teaching comprehension: What teachers should know? Perspectives (TESOL Arabia), 22(1): 11-22.

Obadia, A. \& Thériault, C.M.L. (1997). Attrition in French immersion programs: Possible solutions. The Canadian Modern Language Review, 53(3): 506-529, https://doi.org/10.3138/cmlr.53.3.506.

Pilten, G. (2009). Okuma. Illk Okuma veYazmaÖğretimi (Ed: Pilten, G., Temur. T., Şahin, A., Demir, PegemAkademiYayıncilık.

Sloat, E. A., Beswick, J. F., \&Willms, D. J. (2007). Using early literacy monitoring to prevent reading failure. Phi Delta Kappan, 88 (7): 523-529, https://doi.org/10.1177/003172170708800711.

Syahfutra, W. (2017). Improving Students' Reading Comprehension by Using SQ3R Method. J.E.A.L.T, 8(2): 133-140.

Wood, E., Woloshyn, V. E., \& Willoughby, T. (1995). Cognitive strategy instruction for middle and high schools. Cambridge, MA: Brookline Books. 